\title{
Application of Problem Based Learning Model to Increase Learning Activities and Critical Thinking Skills
}

\author{
R. Wijayanti, Muhari, N. Setyowati \\ Universitas Negeri Surabaya, Surabaya, Indonesia \\ ririnwijayanti1985@gmail.com
}

\begin{abstract}
The purpose of this study is to improve learning activities and skills of critical thinking through the implementation of learning models based on problems in fourth-grade students. This is a classroom action research conducted in two cycles. The subjects were 34 students of grade IV of primary school. Data was obtained from the observation and test. Data analysis technique used is descriptive quantitative.

The finding of the research analysis indicates that learning through the application problem-based learning model can increase the learners' activity and critical thinking skills. The average percentage of students' activity in the first cycle was $70.15 \%$, increased in cycle II by $80.00 \%$. Likewise, the average percentage of critical thinking skills of learners in the first cycle was $70.59 \%$ increase in cycle II by $78.31 \%$.
\end{abstract}

Keywords-Problem-based learning; learning activities; critical thinking skills; 'my area' theme.

\section{INTRODUCTION}

Education minister's regulations No. 57 Year 2014 explains that the purpose of Social studies education is to form creative, critical, religious, honest, democratic citizens with a sense of care and want to know the social and physical environment, develop communication, social life and culture. According to the National Council for the Social Studies (NCSS), social studies aims to assist the younger generation in developing the ability to respond to citizenship issues and make decisions in the public interest. Social studies learning provide an opportunity for students to be able to analyze the important issues that occur in daily activities so as to provide motivation to participate in community life [1].

Therefore teachers should implement meaningful learning that students can achieve that goal. A teacher should always try to prepare the learning program well and systematically. Teachers should provide a fun learning and enable students to follow learning with passion and achieve learning objectives.

The initial observation was performed by giving the student a description. The given question refers to the indicator of critical thinking. Evaluation results show that students' critical thinking skills needed to be improved. As many as
$45 \%$ students from a total of 34 students fell in moderate critical thinking skill criteria. Only some students follow the learning process in the learning activities. When learning, student activities to identify problems, filed and answered the question was still low. The question given is still limited to ask for explanations or concepts.

Other issues that prove the activities of learners need to be improved include (1) many learners are not active to seek their own information from other sources, (2) students tend to sit and listen to material from teachers, (3) students who actively express opinions are limited to some children only, (4) students has low appreciation when there are friends who presented the results of his work.

Based on the problems that have been presented, it is necessary to improve the learning. Lessons learned should be able to grow and develop critical thinking skills in daily activities. Poorly trained critical thinking skills students lead students using only a few of their thinking skills and make students unable to think independently [2].

Critical thinking skills are needed for students to be able to face the challenges of the ever-evolving era of globalization. To face the challenges of the globalization era and the ever-evolving issues of life, critical thinking skills is needed. By thinking critically students can select and adjust the various cultures that fit in accordance with Indonesian culture [3].

Considering the importance of critical thinking skills for students, it needs to be improved. That learning can develop critical thinking skills. Learning can be performed through contextual teaching and learning approach, constructivism, direct observation, application of problembased learning model, and others. Students' critical thinking skills can be trained by exploration, problem-solving, inquiry, and learning through small teams by applying scaffolding approaches that require students to be active in learning.

The researcher's choice falls upon using a problembased learning model. Problem-based learning aims to investigate issues that have been devised to gain knowledge, problem-solving, free learning and good student engagement that requires critical thinking skills. Problem- 
based learning model can develop thinking skills in solving problems. Critical thinking always begins with a problem and results in a solution. This means that critical thinking always starts with a problem and generates a solution [4]. Problem-based learning model tends to familiarize students with problem-solving skills and can improve students' critical thinking skills. An effective problem-based learning model is used for higher-order thinking. This is consistent with several studies that have proven the success of problem-based learning models that can improve critical thinking skills.

Based on the above description, a research entitled "Application of Problem Based Learning Model to Increase Learning Activities and Critical Thinking Skills 'In My Living area' Theme, Primary Four Students is conducted.

The problem-based learning model is also known as PBL model. PBL is a learning that starts with the real problem of acquiring new knowledge, developing problemsolving skills and critical thinking. Based on that opinion, problem-based learning stems from an authentic problem in everyday life. The learners then identify and gather information to address them to build new insights, critical thinking skills and problem-solving. Problem learning model can enable learners because it is student-centred learning [5].

The characteristics of Problem Based Learning include (1) Using authentic issues as a principle of learning, (2) Connecting problems with various science courses and choosing the most appropriate to the facts, (3) Conducting an authentic investigation to solve the problem, 4) Producing a product and present it, (5) Forming a small team and work together.

Steps in the problem-based learning model are different from other learning models. The syntax of problem-based learning models includes five steps presented in the following table [6].

TABLE I. PROBLEM BASED PROBLEM SYNTAX (PBL)

\begin{tabular}{|c|c|}
\hline $\begin{array}{c}\text { Steps } \\
\begin{array}{c}\text { Step 1 } \\
\text { precting learners to the } \\
\text { problem }\end{array}\end{array}$ & $\begin{array}{c}\text { Teachers' Activities } \\
\text { The teacher discusses learning objectives, } \\
\text { important logistical needs, raises problems, } \\
\text { and motivates in finding solutions to a } \\
\text { problem. }\end{array}$ \\
\hline $\begin{array}{c}\text { Step 2 } \\
\text { Organizing learners to learn }\end{array}$ & $\begin{array}{c}\text { The teacher guides the learner to describe } \\
\text { and organize the learners' role related to the } \\
\text { issue. }\end{array}$ \\
\hline $\begin{array}{c}\text { Step 3 } \\
\text { Guiding an }\end{array}$ & $\begin{array}{c}\text { Teachers stimulate learners to gather } \\
\text { appropriate information, conduct } \\
\text { experiments, and seek explanations and } \\
\text { solutions. }\end{array}$ \\
\hline $\begin{array}{c}\text { Step 4 } \\
\text { Develop and represent } \\
\text { products }\end{array}$ & $\begin{array}{c}\text { Teachers guide learners in compiling a } \\
\text { product such as models, reports, and videos, } \\
\text { as well as helping to share assignments with } \\
\text { other learners. }\end{array}$ \\
\hline $\begin{array}{c}\text { Step 5 } \\
\text { problem-solving process }\end{array}$ & $\begin{array}{c}\text { The teacher helps learners reflect on the } \\
\text { investigation. }\end{array}$ \\
\hline
\end{tabular}

In the learning process, the problem-based learning model is related to the learning activities and critical thinking skills of the students. Problem-based learning can spur the creativity of learners and become active and independent learners. Stating that students will no longer be passive learners, they can be more active in learning [7].

The linkage between problem-based learning models and critical thinking skills of learners is also supported by some experts. There are three theoretical and empirical foundations are as follows.

\section{Dewey's opinion}

According to Dewey's view school describes the life of the community as a place to find new information. This supports teachers to include learners in the issues that occur in the environment. The orientation of this problem is closely related to the problem-based learning model. The problems must be solved by the students to gain the solution. To gain solutions to these problems learners must think critically and learn with small groups.

\section{Piaget, Vygotsky, and Constructivism}

Piaget explains that children have a high curiosity about the occupied environment that is always developing. This curiosity motivates the child to be actively involved in building the environment. Every learner is actively involved to build and seek new insights through the thinking process. Science experience changing and evolving when learners are exposed to new experiences to build and modify their initial knowledge.

Vygotsky believes that the insight of human thought is always developed when people experience themselves and try to overcome the challenges that appear in the experience. Vygotsky puts that important role in the development is on social attitudes. Vygotsky believes that social relationships between living things can support and enhance the ideas and knowledge of learners. This relates to a problem-based learning model in which learning occurs through the social interaction between learners, teachers, peers, and other sources that can develop new knowledge and critical thinking skills.

\section{Brunner and Discovery Learning}

Brunner supports discovery learning theory. This learning model can support learners to investigate student information and creativity through discovery. Discovery is used to obtain information, solve problems, and support the development of students' critical thinking skills. According to Brunner, social relationships between people and the environment enables learners to solve problems critically. Based on the above theories, a research entitled "Application of Problem- Based Learning Model to Increase Learning Activities and Critical Thinking Skills is conducted. 


\section{RESEARCH METHODS}

This is a Classroom Action research. Subjects in this study are 34 students of fourth-grade students; consisting of 18 male students and 16 female students. This study consists of 2 cycles. Data collection techniques are observation and test. Observation sheet is used to collect students' activity data. The test sheet is used to measure the learners' critical thinking skills. The test sheet provided is an essay written test.

Classroom Action Research is a study in the form of action activities in the implementation of learning activities conducted intentionally in the classroom to solve the problems of learning in the classroom and further actions to improve the skills of learners. The research design is as follows.

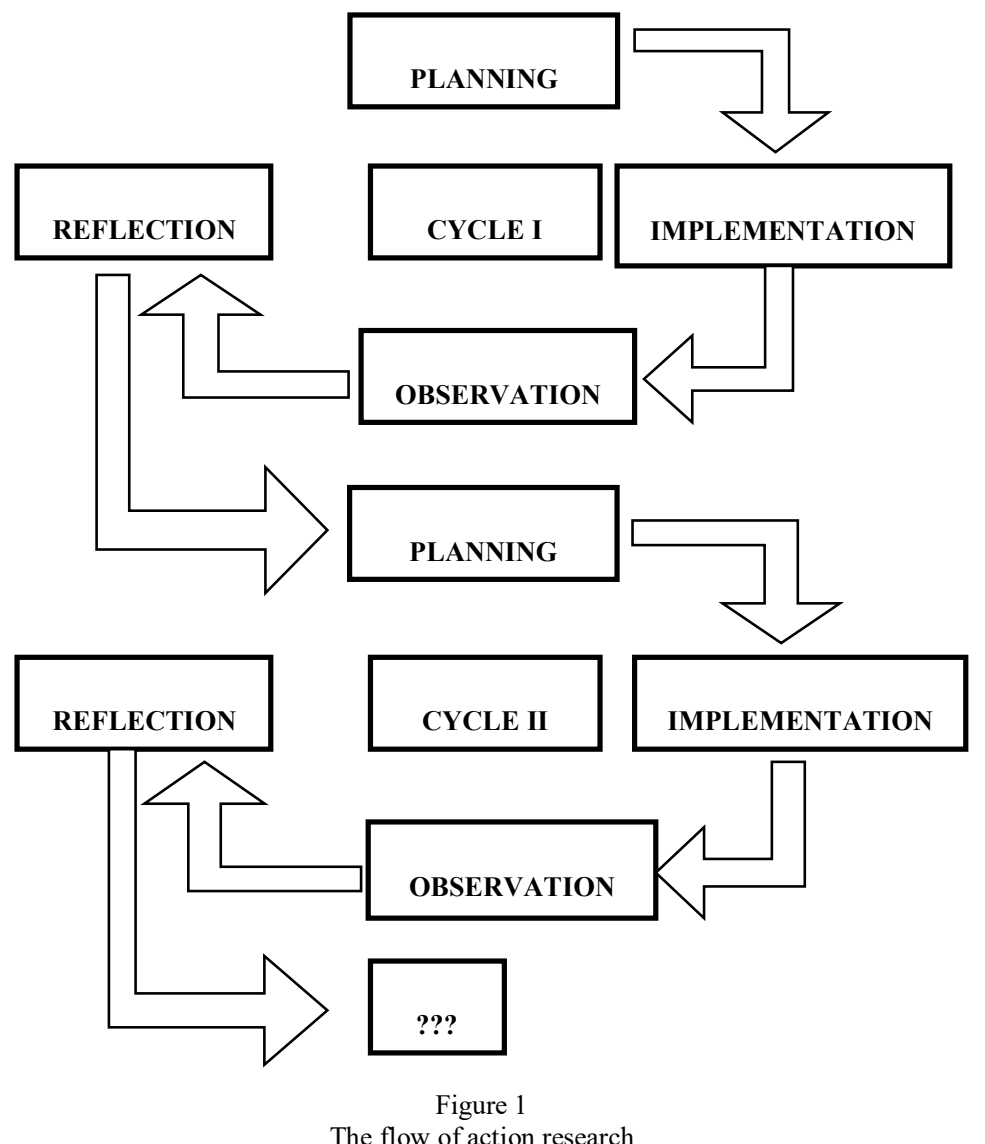

1. Planning, prior to conducting research, the researchers develop learning tools and research instruments

2. Implementation, at this stage the researchers implement learning by applying the model of learning based on the problem in accordance with the planned implementation of learning that has been prepared.

3. Observation, at this stage, the observer observes the behaviour/activity of learners and the activity of the teacher in accordance with the prepared observation sheet.

4. Reflection. At this stage researchers and observers discussed the results of observations on the activities of learners and concluded whether the learning activities have reached the indicator or not. The researcher analyzes the critical thinking skills of the students based on the question of critical thinking skills about the economic activities that the students have done and concluded whether the critical thinking skills of the students meet the expected criteria yet. In this research, research data is analyzed by the quantitative descriptive technique by using the following formula.:

$P=\frac{F}{N} \times 100 \%$

Where:

$\mathrm{P}$ : the percentage of the number of learner activity that appears

F: number of acquisition scores (number of learner activity scores that appear)

$\mathrm{N}$ : maximum number of scores (total score of an aspect of activity as a whole) [8].

TABLE II.STUDENTS ACTIVITIES SUCCES CRITERIA

\begin{tabular}{|c|c|}
\hline Quantitative value & Criteria \\
\hline $81-100$ & Very good \\
\hline $61-80$ & Good \\
\hline $41-60$ & Moderate \\
\hline $21-40$ & Low \\
\hline $5-20$ & Very low \\
\hline
\end{tabular}

Data analysis of critical thinking skills is gained by using the following formula.

$M=\frac{\sum F}{N} \times 100 \%$

Where:

$\mathrm{M}=$ learners' critical thinking skills

$\Sigma \mathrm{F}=$ score obtained by the student

$\mathrm{N}=$ maximum score [9]

\section{RESULT AND DISCUSSION}

The finding is elaborated as follows.

\section{A. Learners' Activity}

Based on data of observation, the average of activity percentage in cycle I was $70,15 \%$ which falls into the good criterion. However, this percentage has not reached the indicator of research success by $\geq 75 \%$. Thus, the research was continued on cycle II. From the implementation of learning in cycle II the average percentage of learners' activities was $80.00 \%$ with good criteria. Thus, the percentage of student activity in cycle II has reached the indicator of success. Therefore, the present research is successful in improving the learning activities.

This increase is in line with the research showing that the application of problem-based learning (PBL) model can increase learners' learning activity in learning process compared with conventional learning [10]. 
TABLE III. OBSERVATION DATA OF STUDENTS' ACTIVITY

\begin{tabular}{|c|l|c|c|}
\hline \multirow{2}{*}{ No } & \multicolumn{1}{|c|}{ Section observed } & \multicolumn{2}{|c|}{ Percentage (\%) } \\
\cline { 3 - 4 } & & Cycle I & Cycle II \\
\hline 1 & $\begin{array}{l}\text { Student attention to teacher's } \\
\text { explanation of material } \\
\text { identification }\end{array}$ & 75,74 & 84.56 \\
\hline 2 & Cooperation in groups & 67.65 & 79.41 \\
\hline 3 & $\begin{array}{l}\text { Expression of opinion in the } \\
\text { group }\end{array}$ & 71,32 & 81.62 \\
\hline 4 & $\begin{array}{l}\text { Showcase and presentation of } \\
\text { the work }\end{array}$ & 67.65 & 77.21 \\
\hline 5 & $\begin{array}{l}\text { Analysis and evaluation of } \\
\text { material }\end{array}$ & 68.38 & 77.21 \\
\hline \multicolumn{2}{|c|}{ Average learner activity } & $\mathbf{7 0 . 1 5}$ & $\mathbf{8 0 . 0 0}$ \\
\hline
\end{tabular}

(Source: field data processed by the researcher)

Data analysis of learning activities is shown in the following graph of the percentage of students' activity in the following figure.

In cycle II, data of critical thinking skill reached $78,31 \%$ falling to good criteria. Thus, the percentage of critical thinking skills in cycle II has reached the success indicator of the research. Thus, the present research is successful in improving the critical thinking skills of learners on the application of learning model based on the problem of fourth-grade students on the theme of my area.

The results indicate that the use of problem-based learning model (PBL) can inculcate the critical thinking skills of learners better than using conventional learning model [11] . The results of data analysis of critical thinking skills tests on the application of problem-based learning model on the theme of my residence in grade IV students can be seen in the following table.

TABLE IV. DATA OF CRITICAL THINKING SKILLS PER INDICATOR

\begin{tabular}{|l|l|c|c|}
\hline \multirow{2}{*}{ No } & \multicolumn{1}{|c|}{$\begin{array}{c}\text { Indicators of Critical Thinking } \\
\text { Skills }\end{array}$} & \multicolumn{2}{|c|}{ Percentage (\%) } \\
\cline { 3 - 4 } & \multicolumn{1}{c|}{ Cycle I } & Cycle II \\
\hline 1 & Identify the problem & 74.26 & 82.35 \\
\hline 3 & $\begin{array}{l}\text { Determine the cause of the problem } \\
\text { problem }\end{array}$ & 71,32 & 78.68 \\
\hline 4 & Determine the solution & 69.12 & 77.21 \\
\hline $\begin{array}{l}\text { The average percentage of Critical } \\
\text { Thinking Ability }\end{array}$ & 67.65 & 75.00 \\
\hline
\end{tabular}

(Source: field data processed by the researcher)

Based on the results of data analysis of critical thinking activities skills of learners above, the graph of the percentage of

success critical thinking skill is shown in the following picture.

n

$\frac{74}{\% 2}$

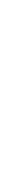
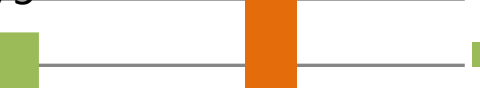

Students'
activities
success

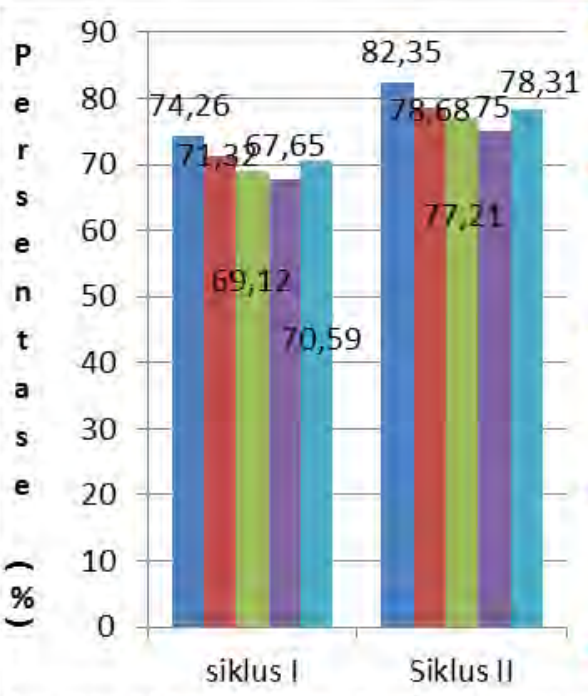

Average of percentage of critical thinking skills

Identify the problem

Determine the cause of the problem

Determine the impact / effect of the problem

Determine the solution

Average percentage of Critical Thinking Ability

Figure 3

Average Graph of Percentage of Critical Thinking Skills Reviewed Per Indicator

(Source: field data processed by the researcher) completing the test. consequently, the quality of learning still needs to be improved. 
TABLE V. DATA RESULTS OF SUCCESS INDICATORS

\begin{tabular}{|l|l|c|c|}
\hline \multirow{2}{*}{ No } & \multicolumn{1}{|c|}{$\begin{array}{c}\text { Indicators of Successful } \\
\text { Research }\end{array}$} & \multicolumn{2}{c|}{ Percentage (\%) } \\
\cline { 2 - 4 } & \multicolumn{1}{|c|}{ Cycle I } & Cycle II \\
\hline 1 & Learners' activities & 70.15 & 80.00 \\
\hline 2 & $\begin{array}{l}\text { Learners' Critical thinking } \\
\text { skills }\end{array}$ & 70.59 & 78.31 \\
\hline
\end{tabular}

(Source: field data processed by the researcher)

Based on the data analysis above, learning using the problem-based learning model can improve learning activities and critical thinking skills of learners. The problem-based learning model is a learning that uses real problems and is open to learners to develop problem-solving skills, critical thinking, and building new knowledge [12]. The following can be seen in the percentage of success indicator graphs in the following figures.

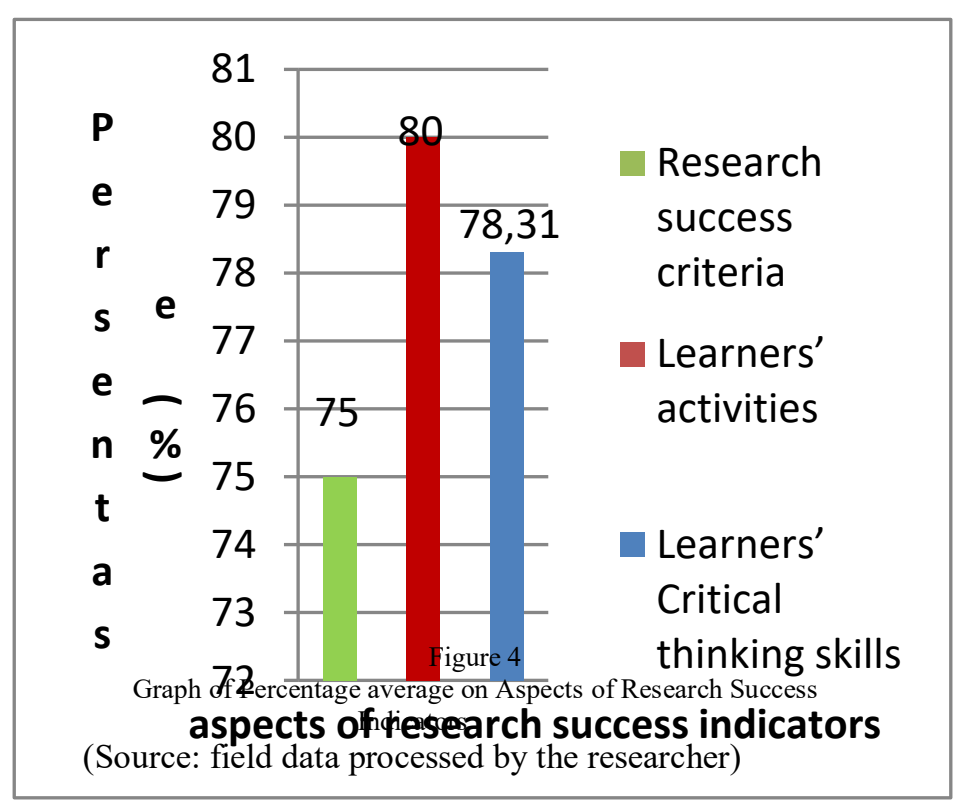

IV. CONCLUSION

Implementation of the problem-based learning model can improve learning activity and critical thinking skills on the theme of 'my living area' of fourth graders. The increase is shown in cycle II reaching successful learning indicators on activities and critical thinking skills by $\geq 75$.
Teachers should use a problem-based learning model to improve their activities and critical thinking skills by adapting other learning materials delivered to learners as well as research.

\section{REFERENCES}

[1] Nasution. Kajian pembelajaran IPS di sekolah. Surabaya: Unesa University Press. (2011).

[2] Setyorini, dkk. Penerapan model problem based learning untuk meningkatkan keamampuan berpikir kritis siswa SMP. Jurnal Pendidikan Fisika Indonesia, 7 (2011), 52-56. (2011).

[3] Kusmijati, Neneng. Peningkatan kemampuan berpikir kriti menggunakan model problem based learning pada siswa kelas VIII F SMPN 2 Purwokerto. Jurnal pendidikan geografi, 39-47. (2016).

[4] Meyers, Chet. Teaching students to think critically. California: Jossey-Bass. (1991).

[5] Sada, dkk Prospects of Problem based learning in building critical thinking skills among technical college students in Nigeria. Mediterranean Journal of Social Science, 7 (3), 356-365. (2016).

[6] Arends, Richard. Learning to teach edisi 9. New York: McGraw-Hill. [15] Sugiyono. (2010). Educational Research Methods. Bandung: Alfabeta. (2013)

[7] Major dan Mulvihil. Problem-based learning pedagogies in teacher education the case of Botswana. Interdisciplinary Journal of Problem Based Learning, 12 (1), 1-11. (2017).

[8] Sudjana dan Ibrahim. Penelitian dan penilaian pendidikan. Bandung: Sinar baru Algesindo. (2012)

[9] Supardi. Penilaian autentik pembelajaran afektif, kognitif, dan psikomotor. Jakarta: PT Raja Grafindo Persada. (2015).

[10] Ejin, Syahroni. Pengaruh model problem based learning (PBL) terhadap pemahaman konsep dan keterampilan berpikir kritis siswa kelas IV SDN jambu Hilir Baluti 2 pada mata pelajaran IPA. Jurnal Pendidikan, 1 (1), 65-71. (2016).

[11] Siew dan Mapeala. The effects of problem based learning with thinking maps on fifth graders' science critical thinking. Journal of Baltic Science Education, 15 (5), 602-616. (2016).

[12] Fathurrohman, M. Model-model pembelajaran inovatif. Yogyakarta: arRuzz Media. (2016). 